\title{
The trajectory of livestock performance in India: A review
}

\author{
Raka Saxena $^{1}$, Mohd Arshad Khan ${ }^{1}$, Bishwa Bhaskar Choudhary ${ }^{2}$ and Vinita Kanwal ${ }^{1}$
}

Received: 20 October 2019 / Accepted: 28 October 2019 / Published online: 31 December 2019

(C) Indian Dairy Association (India) 2019

\begin{abstract}
This paper presents the growth trajectory along with key dimensions related to livestock marketing, trade, animal health services, feeding pattern along with the impact of climate. India's livestock sector is both expanding and acclimatizing to the emerging socioeconomic, environmental, and technological dynamics. Growing importance of livestock towards enhancing food and nutritional security, increasing agricultural growth, reducing rural poverty and mitigating farm households' vulnerability to shocks in along with providing employment and empowerment opportunities to females has been widely acknowledged and acclaimed in numerous studies. A modernization perspective is required for the sector for technological innovations and help to overcome the challenges associated with shifting production, consumption and changing climate. The future growth in livestock sector needs to be focused on productivity and efficiency. Newer science tools will enhance animal productivity and make the sector a more profitable occupation. The country needs to focus on the niche items for exports and niche destinations along with addressing the safety issues. Gradual stress induced by global warming and climate change is also influencing fertility and productivity of livestock, the potentiality of science and livestock research should be harnessed by validating and transferring the technologies for enhancing animal productivity, improved value addition and improving competitiveness. Efficient and effective extension services, sufficient feeds \& fodder, effective animal health
\end{abstract}

${ }^{1}$ ICAR-National Institute of Agricultural Economics and Policy Research, New Delhi, India

${ }^{2}$ Department of Economics and Sociology, Punjab Agricultural University, Ludhiana-141001, India

Raka Saxena $(\square)$

ICAR-National Institute of Agricultural Economics and Policy Research, New Delhi, India

Email: rakasaxena@gmail.com services, incentives for shift from subsistence livestock to livestock entrepreneurship along with efficient chains for livestock marketing and trade would be the game changers.

Keywords: Community employment, Livestock marketing, Nutritional security, Sustainable agricultural production

\section{Growth in Livestock Sector}

Livestock are an integral component of agriculture in India and make multifaceted contributions to the growth and development of agricultural sector as well as overall economy. Livestock contributes significantly in food stream, nutrition, income, asset savings, soil productivity, livelihoods, transport, agricultural traction, agricultural diversification and sustainable agricultural production, family and community employment, social status and also performs few other functions (Bettencourt et al. 2015). The sector is also being considered to play promising role in the ambitious goal of the government to double the farmer's income by 2022 (Chand, 2017; Das and Kumar, 2017). Growth in demand for livestock products is primarily expected to escalate due to human population growth, increasing urbanization and rising income, as the demand for livestock products is income elastic. These developments present enormous opportunities to boost farmers' income, especially in less developed region (Saxena et al, 2017) and accelerate the pace of poverty reduction. Livestock sector in India has strong backward and forward linkages and promote many industries like livestock-based food processing and leather industries (Kumar et al, 2007). Livestock sector is growing at an appreciable rate (Box 1). Researchers have emphasised about the growing importance of livestock in the gross domestic product (GDP) (Birthal, 2006; Birthal and Taneja 2012). The gross value added (GVA) from livestock sector contributed 4.1 per cent to the total GVA and 27.5 per cent to the agricultural GVA in 2017-18.

Vast livestock and poultry resources play a vital role in improving the socio-economic conditions of rural masses. Huge animal population with adaptability to wide range of agro-climatic conditions in the country is a vital asset and provides scope for diversified agriculture. There are 302.8 million bovines, 74.3 million sheep and 148.9 million goats in the country as per the $20^{\text {th }}$ 
livestock census. A decline of 6 per cent in the total indigenous cattle population has been noted in $20^{\text {th }}$ livestock census over the previous census. With increased mechanization of crop production and declining farm size making many marginal farmers unable to keep draught cattle, the utility of indigenous cattle has been decreasing (Srivastava et al. 2017). Moreover, indigenous cattle produce lower milk yield than buffaloes, so there is a tendency to replace indigenous cattle with buffaloes and crossbred cattle once the need for draught power is over. The buffalo population has increased from 84.2 million in 1992 to 109.8 million in 2019. The population of crossbred cows has also increased at the rate of 3.5 per cent per year during 2012-19. Indigenous animals have the advantage of sustaining productivity under low inputs and are also known for their drought tolerance and disease resistance (Nyamushamba et al. 2017). Saxena et al. (2017) have strongly emphasized on promotion and support for crossbreeding in less developed region as the crossbred adoption and productivity significantly enhance farmer's income.

The population of small ruminants which had declined in 2012 has appreciably increased in 2019. The total sheep and goat in the country have increased in 2019 by 1.9 and 1.4 per cent, respectively per year over the previous census. The total poultry population in the country has increased by 16.8 per cent over the previous census and stood at 851.8 million in 2019. Goats and sheep play significant role in food and nutritional security of the rural poor. Goat rearing has distinct economic and managerial advantages over other livestock species because of its less initial investment, low input requirement, higher reproductive rate, early sexual maturity, and ease in marketing (Kumar et al. 2010). Poultry is one of the fastest growing segments in the livestock sector. This industry has grown largely due to initiative of private enterprise, huge indigenous poultry genetic resources, and considerable support from complementary veterinary health, poultry feed, poultry equipment and poultry processing sectors (Priya et al. 2015). A significant feature of India's poultry industry has been its transformation from a mere backyard activity into a major commercial activity in just about four decades, this transformation has involved the sizeable investments in breeding, hatching rearing and processing.

Livestock production includes milk, meat, eggs, wool, dung, honey, silkworm cocoons etc. The major livestock food products are milk and meat. The milk group contributes highest (about two-third) share in the value of production from livestock sector. Milk production is continuously increasing since the initiation of operation flood in the early seventies on account of improved technological changes and creation of market linkages between rural producers and urban consumers through the network of dairy cooperatives (Birthal and Taneja, 2006) and India continues to be the largest producer of milk in world. Several measures have been initiated by the government to increase the productivity of livestock, yet the productivity is low as compared to many other countries and the world average. Buffalo and cattle are important milch species and contribute 49 and 47 per cent, respectively, in total milk output in 2016-17. The growth in milk production was higher in case of cattle as compared to buffaloes and goats during last decade (Box 1). The meat production from different species has grown at varying rates. While, cattle meat (beef) production showed a mixed trend, the meat production from buffalo significantly increased from 413 thousand tonnes in 2001-02 to 1611 thousand tonnes in 2016-17 (Box 1). The meat production from other species has also considerably increased during the same period; the meat production structure, however, changed drastically during 2010 to 2016 . As livestock sector is emerging as a potential source of agricultural growth and incomes, this paper presents the growth trajectory along with key dimensions related to livestock marketing, trade, animal health services, feeding pattern along with the impact of climate. These dimensions are discussed in the current and subsequent sections.

\section{Gender Participation and Income Generation through Livestock}

The studies have highlighted the growing importance of livestock towards enhancing food and nutritional security, increasing agricultural growth, reducing rural poverty and mitigating farm households' vulnerability to shocks in production (Akter et al. 2008, Birthal and Negi, 2012). The studies have also reported that growth in livestock has greater potential to reduce poverty as compared to the similar growth in crop sector (Mellor, 2004; Birthal and Taneja, 2006). Women also play important role in livestock management. It is important to identify and support women's role as livestock owners and processors and in promoting their economic and social empowerment along with strengthening their decision-making power and capabilities (IFAD, 2003). Livestock sector is unique in terms of providing employment and empowerment opportunities to females, two-third of female workforce in rural India is engaged in livestock rearing (Kumar and Singh, 2008). Further, women being in control of asset and having role in household decision lead to an improvement not only in their own welfare but also in household food security along with child nutrition and education (World Bank, 2010; Quisumbing and Maluccio, 2003; Smith et al. 2003). The ownership of livestock leads to an improved household income which will further direct investment towards purchase of nutritious food items and enhanced healthcare facilities (Senauer, 1990). Hitchings (1982) recognized a positive relationship between child height and ownership of a milk cow, conditional on milk being used for family consumption. Duflo (2003) emphasized that livestock can be owned and used by women to consolidate their bargaining power in intra-household resource allocation decisions. Livestock can be easily purchased with a small investment and can be multiplied to accumulate wealth and savings being a reproductive asset and is less prone to external shocks such as droughts and floods (Alary et al. 2011; Birthal and Negi, 2012).

\section{Consumption and Demand for Livestock Products}




\section{Gross Value Added at 2011-12 Prices (Rs Crore)}

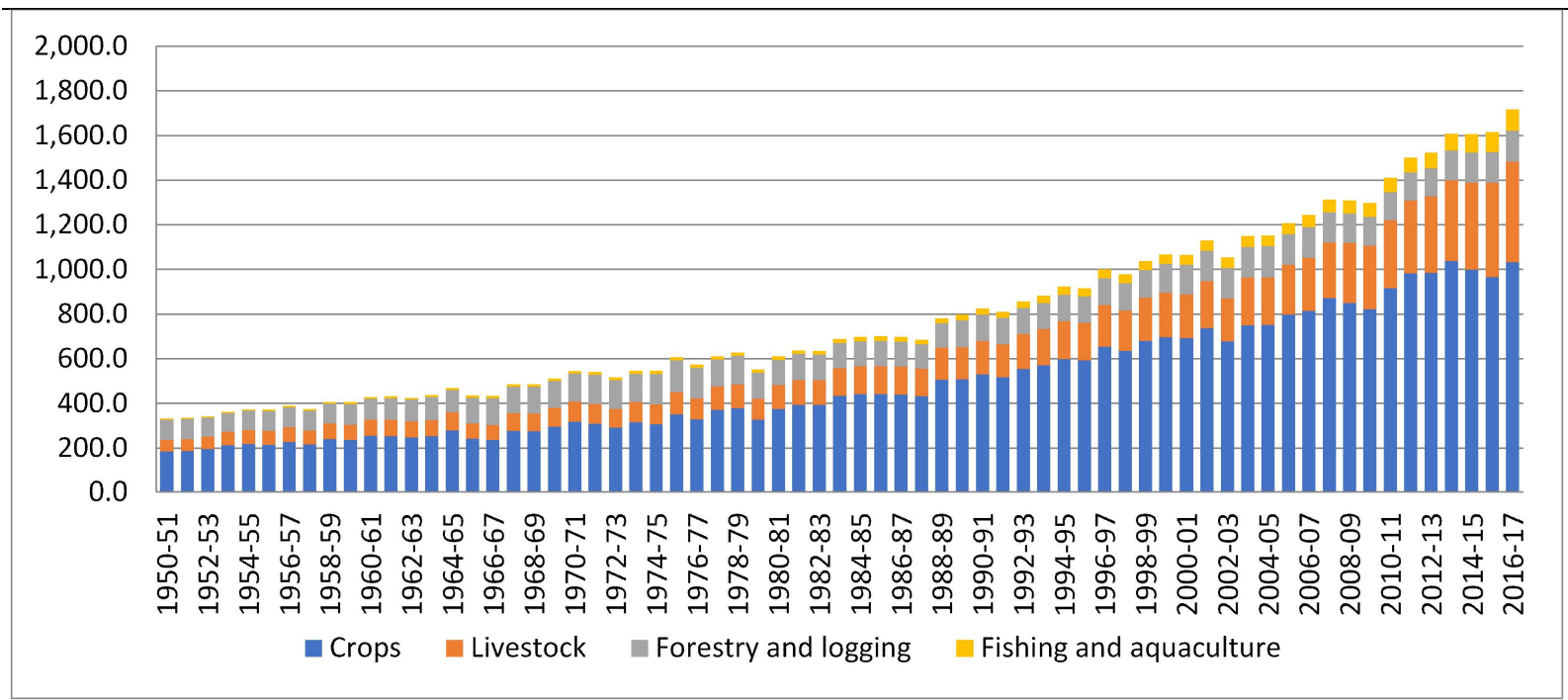

Box 1. Trends in Livestock Output and Population

The role of livestock in nutritional security is also immense. Livestock products are rich source of high quality protein, minerals, vitamins and micronutrients. Animal proteins are more digestible and metabolized more efficiently than plant proteins (Berrazaga et al. 2019). Meat, milk and eggs provide proteins with a wide range of amino acids that match human needs, as well as many bio-available micro-nutrients such as iron, zinc, vitamin A, vitamin B12 and calcium, for which many malnourished people are deficient (Górska-Warsewicz et al. 2018). Considering the nutritional importance of such high value products, the dietary patters have changed overtime in India. With increase in incomes, a pronounced shift is noted in consumption of livestock products (Fig 1). There is a clear shift towards fruits and vegetables, livestock products and fisheries. Mittal (2007) advocated that the increase in relative prices of cereals vis-à-vis other food commodities, diversification towards high-value food and changes in taste and preferences are responsible factors for the decline in cereal consumption. Gandhi and Zhou Zhang-Yue (2010) illustrated that there has been a rapid rise in the demand for livestock products in India. Liquid milk consumption in India has considerably increased over last two decades from 1993-94 to $2009-10$, the per capita consumption of liquid milk increased by 18.9 percent in rural areas and 65.1 percent in urban areas (Kumar et al. 2014). There has been significant increase in consumption pattern of egg, fish and chicken in both rural as well as urban India.

Based on household data of various rounds of national sample survey (NSS), Kumar (2016) projected the demand and supply of major food commodities in India by 2020 and 2030. The study indicated that the consumption pattern is changing towards high value commodities including livestock. A recent study by NITI aayog reported that demand for liquid milk for household consumption is projected to reach 78 million kilolitres in 2021-22 and 90 million kilolitres by 2032-33, further the aggregate demand for milk will touch 220 million kilolitres in 2032-33; while demand for eggs, fish and meat will be 25 million tonnes (NITI, 2018). With rise in demand for animal food products, there are significant opportunities for enhancing agricultural growth and reducing rural poverty (Birthal, 2012). Several other studies established the changing consumption pattern and projected the future demand for various commodities in India (Kumar et al. 2011; Kumar and Dey, 2007). The studies have also estimated price and income elasticities of various food products. Income elasticities are maximum for milk (1.64), followed by sugar (0.94), vegetables \& fruits (0.82), edible oils (0.77), pulses (0.72) and least for cereals (0.19) for all income groups (Kumar et al. 2011). It implies that demand for milk will increase much faster as compared to other food commodities with increase in income.

\section{Livestock Marketing}

Marketing of milk remains largely into the unorganized sector, 80 per cent of the milk produced by the rural producers is handled by the unorganized sector and remaining 20 per cent is handled by the organized sector; involvement of intermediaries; lack of bargaining power, lack of infrastructure facilities for collection, storage, transportation, and processing were reported as the major constraints affecting the prices received by milk producers (Rajendran and Mohanty, 2004). A study by the world bank reveals that nationally about 40 per cent of milk output is consumed by producers themselves and 60 per cent is marketed - 36 per cent through informal traditional chains and 24 per cent through organized formal ones (World Bank, 2011). Milk is highly perishable product and has highly distributed production system located far from consumer markets. Thus, it requires efficient 
marketing and processing along its entire value chain (from production to consumption) to realize its best value. Milk moves from producers to consumers through different value chains depending on the production system (Fig 2).

Dairy co-operatives, which first started in Gujarat and spread throughout the country with the Operation Flood programme, are the largest player in the organized segment of the value chain (Sirohi et al. 2012). The empirical evidence indicates that although over the years, dairy co-operatives have played a significant role in production, marketing and processing of milk and dairy products (Candler and Kumar, 1998; Cunningham, 2009), thereby contributing towards livelihood security of the millions of milk producers in the country (Singh and Pundir, 2000). However, due to their skewed concentration in few states from west and south of the country their performance and impact is not universally discernible across the entire length and breadth of the country. Most of meat is sold in unpacked form, packed only in some organized meat factories and in bacon factories (Gadekar and
Shinde, 2011).Safe handling of meat and meat products at different stages of processing and marketing is extremely important. Contract farming in poultry has emerged in big way for taking the poultry farming down to the path of industrial farming (Birthal, 2008).

Livestock value chain analysis is essential for understanding of markets, their relationships, the participation of different actors, and the critical constraints that limit the growth of livestock production and consequently the competitiveness of smallholder farmers (IFAD, 2010). The studies have reported that majority of the small farmers in dairy value chains in India still resort to borrowings from the informal sources, viz. moneylenders, traders and input dealers, who often charge high rates of interest (Birthal et al. 2017). Dairy processors should strengthen these chains by providing technology, quality inputs and extension services to the dairy farmers that may help them improve milk yield, reduce cost of production and earn more profit (Birthal et al. 2017).

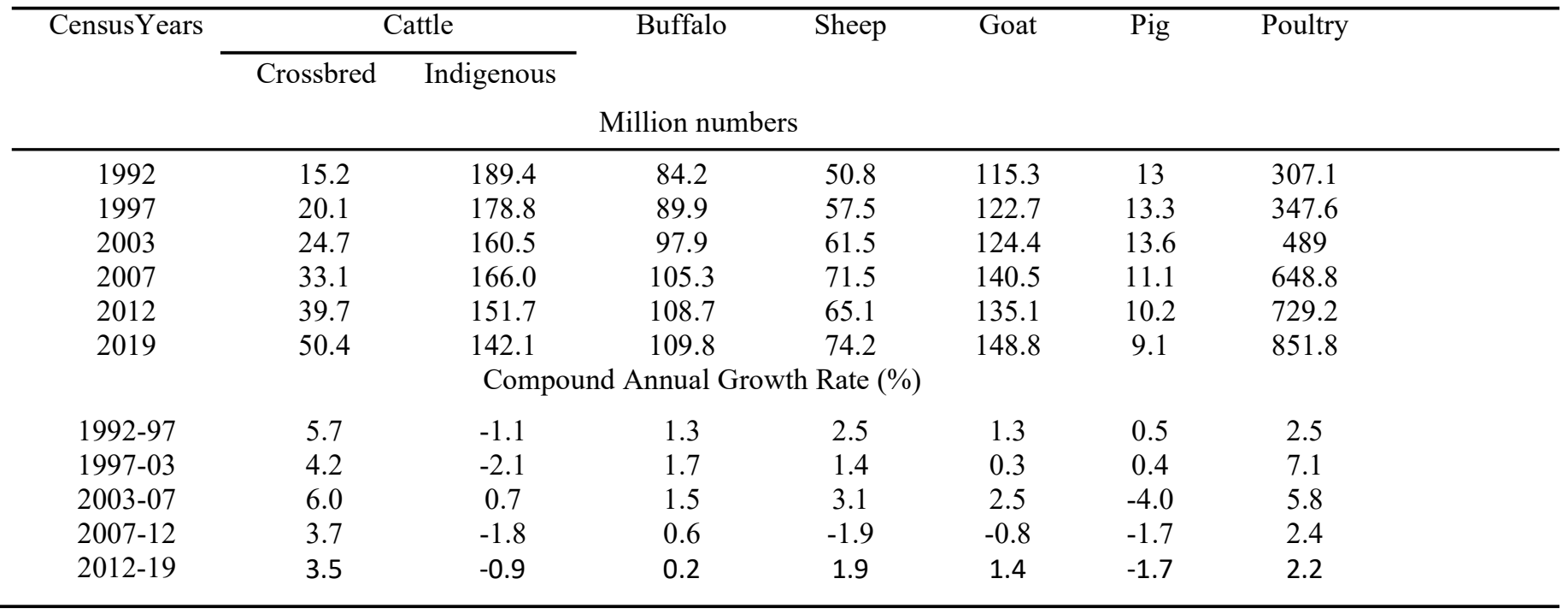

Livestock Production

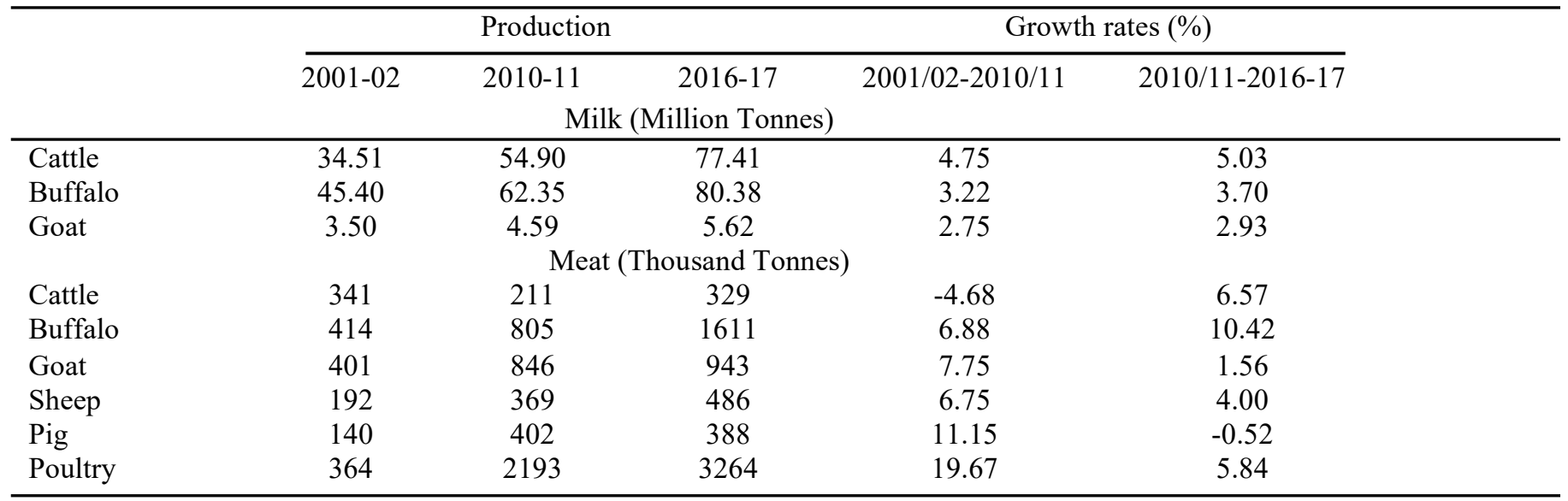

Source: National Account Statistics, Livestock Census and DAHD Annual Report (Various issues) 
Fig. 1 Consumption pattern of major items (Per person per month)

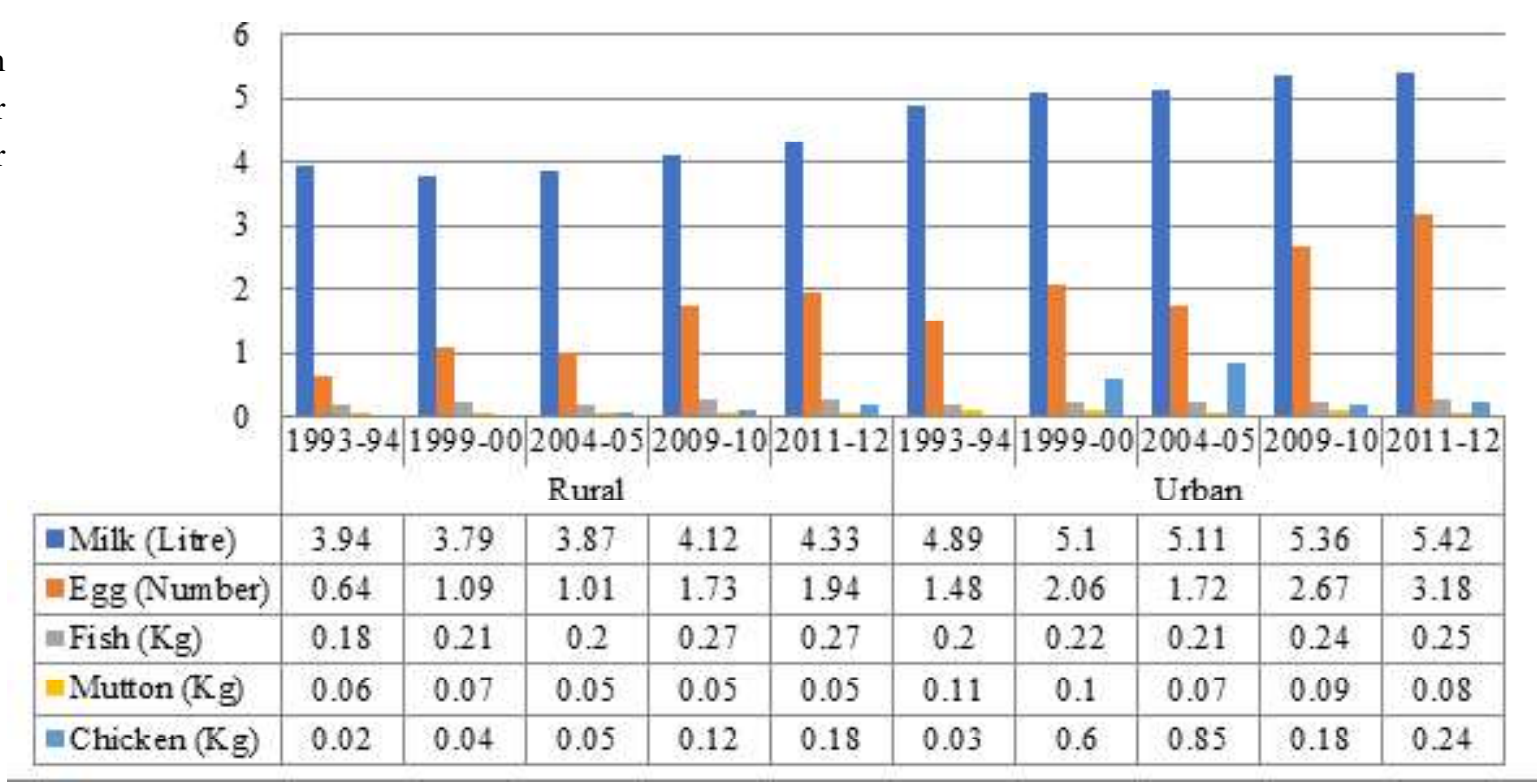

tonnes of buffalo meat, worth Rs 25168 crore, was exported from India in 2018-19.

Livestock products account for about one-fifth of the global trade of agricultural products. India, however, does not have a significant presence in global livestock trade and shares only less than one per cent of world exports and imports. The global market for animal based foods has been expanding rapidly (Birthal and Taneja, 2006), livestock trade is expected to be an important economic activity in coming future. Fig 3 provides the composition of livestock exports from India. In live animal category, sheep and goats have major share in value terms. Bovine meat has been a major export commodity with around 70 per cent share in the total livestock exports from India. Kumar (2010) examined temporal changes in the composition of livestock exports, the export of buffalo meat was reported increasing consistently and the lower domestic demand was cited as an important reason. In milk and milk products, India has some advantage at farm level, but is not competitive in export of these products under the prevailing world market situation (Kumar, 2010). Basically Indian milk producers are not able to adhere to food safety standards prescribed by different milk and milk products importing countries (Rao et al. 2014). Herd size, education level, expertise in dairying, and integration of dairy farmers with modern milk supply chain have positive influence on the adoption intensity of food safety practices at the farm level (Kumar et al. 2011). Bardhan (2007) revealed that exports of India in meat and meat preparations, milk products and eggs have gone up considerably in value terms during the period 1980-2004. The dominance of buffalo meat in total export from livestock products and its increasing share in agricultural export, especially from the year 1993 owing to abolition of minimum export price condition, has been well recognised (Birthal, 2008; Kumar, 2010; Sirohi and Chauhan, 2011). It contributed around 83 per cent to the total export of animal products from India in 2018-19 (APEDA). Around 1.23 million
It has been noted that importing countries impose stringent norms than those specified by Codex without any scientific basis (Goyal, 2017). Further, the absence of information and lack of transparency on the procedural norms and regulations of importing countries as related to specifications as well as methods of sampling, inspection and test add to the worries of livestock exporters (Kumar, 2010). Although, there is flexibility on implementation of HACCP system has been provided for, some countries are insisting on installation of certain infrastructural requirements. Therefore, it becomes essential to work towards harmonizing standards within the country as well as at regional level. Bilateral and multilateral agreements may be signed for recognition of the equivalence of specified sanitary and phyto-sanitary (SPS) measures (Kennedy, 2000). The exporting countries may take advantage of the provisions of the SPS Agreement and international standards and address their concerns jointly through active involvement in international standards (WTO, 2001).

Although livestock exports have registered a commendable rise and liberalisation policies seem to have further augmented their growth, but non-tariff barriers like stringent SPS standards, technical barriers to trade (TBT), anti-dumping duties, countervailing duties, etc., are emerging as the major constraints in tapping the benefits of export potential of the livestock sector (Kumar et al. 2007). Increasing stringent food safety requirements, especially in chief markets such as the EU, US and Japan are emerging as major challenges in the export of food commodities from India and the country should look into other aspects like the cost of compliance, investment required, handling and processing and traceability of the products to boost the livestock exports (Kumar, 2009). 


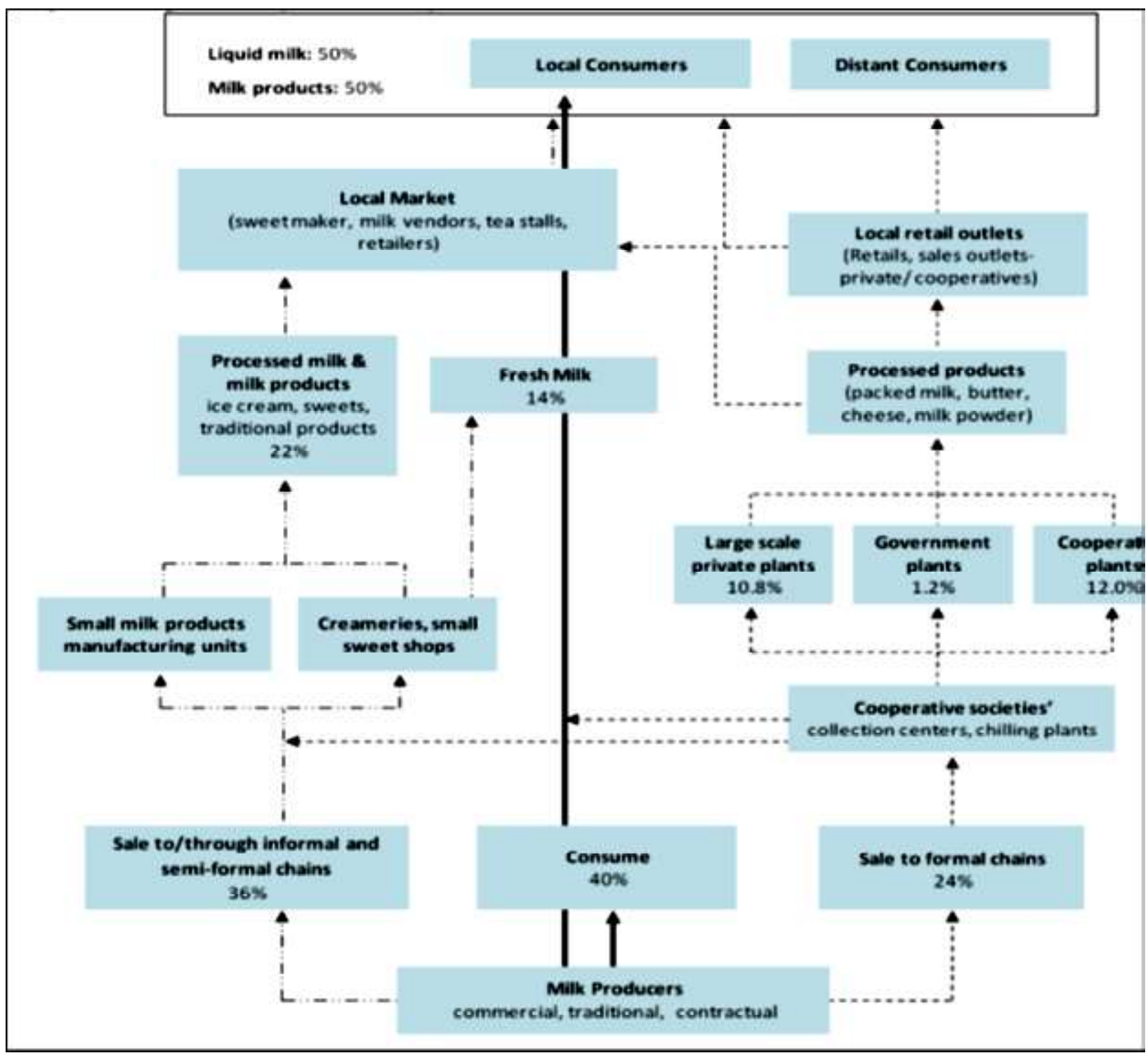

Fig 2. Marketing channels of milk and milk products in India

\section{Livestock and Climate Change}

Climate change has complicated impact on livestock performance. Climate strongly influences the growth, production (Choudhary and Sirohi, 2019; Choudhary, 2017; Kanwal 2018), reproduction (Nardone et al. 2010), health and well-being of the livestock through affecting animal physiology; incidence of disease (Nardone et al. 2010; Thornton et al. 2009) feed, fodder and water availability etc. Increasing climate variability is expected to surge livestock production risks in addition to reduced capacity of farmers to cope up with these risks. The anticipated rise in temperature between 2.3 and $4.8^{\circ} \mathrm{C}$ together with increased precipitation resulting from climate change is likely to reduce the total area in the country where high yielding dairy cattle can be economically reared (Sirohi, 2007).
Dairy cattle are particularly more susceptible to increased ambient temperature than other ruminants because of their high metabolic rate and poor water retention mechanism in gastrointestinal tract (Gaughan et al. 2009; Bernabucci et al. 2010). Excessive heat and humidity causes heat stress in dairy animals which induces physiological changes resulting in reduced feed intake and metabolic activity and thereby declining their productivity (NRC, 2001). Lactating dairy cows exposed to high ambient temperature, often coupled with high relative humidity or radiant energy usually respond with reduced milk yield (West et al. 2003) and which is one of the major economic impacts of climatic stress in dairy cattle. Intensification of thermal stress and more frequent occurrence of this problem is probably the most obvious consequence of global climate change in dairy cattle which is attributable to increased atmospheric temperature. The possibility that the problem of thermal stress to become more prominent 
Fig 3. Composition of export of livestock and livestock products (\$ Thousand)

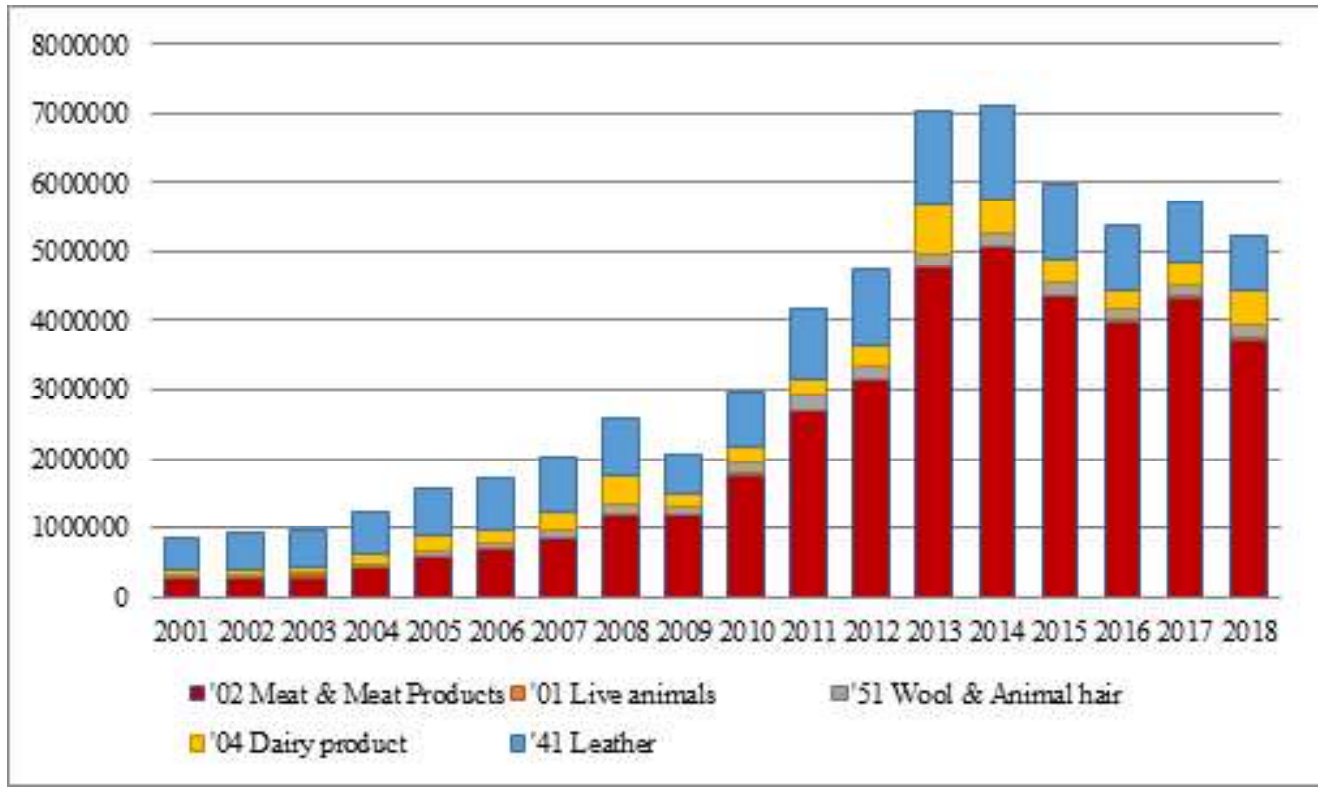

with increased atmospheric temperature in future cannot be overlooked. Concurrently, livestock food chains are major contributors to greenhouse gas emissions, accounting to approximately 18 per cent of whole anthropogenic emissions (Steinfeld et al. 2006). Pankaj et al (2013) suggested greenhouse gas emissions by the livestock sector should be cut by as much as 30 per cent through the wider use of existing best practices and technologies.

Several studies have attempted to examine the impact of climatic variables on different aspects of livestock. During early 70s Maust et al. (1972) reported the variation in milk yield (9\%), milk fat $(13 \%)$, feed intake $(5 \%)$ and rectal temperature due to temperature and humidity index (THI) attributable to weather condition. Later on Choudhary (2017) in trans and upper-gangetic plains of India also confirmed the drastic effect of THI on milk production. Choudhary and Sirohi (2019) reported significant decline in productivity of buffaloes due to heat stress. Upadhyay et al (2008) worked out the animal stress level due to temperature rise using THI in India and concluded an increase in stress due to increased temperature. They also revealed that increase in number of stressful days (THI more than 80) and their frequency will impact yield and production of cattle and buffaloes. Dhakal et al. (2013) concluded that climate change had negative impact on milk production and lactation length and infertility in Nepal. Berman (2005) and Nardone et al. (2010) revealed that when high milk producing cattle were kept in hot climatic zones, metabolic heat production was intensified that resulted in an increased respiratory rate, consequently, decrease in the milk production.

Sirohi (2007) reviewed the sensitivity of livestock production to climate change and indicated likely effect of climate change on Indian livestock. Study suggested that livestock development strategy should focus on minimization of potential production losses and should intensify efforts for methane abatement from this sector. This would be instrumental in increasing production of milk by reducing energy loss from the animals through methane emissions. Later, Kumar et al. (2015) reported that weather variables like rainfall and maximum temperature do significantly influence the milk productivity of animals in rainfed regions. Increased climatic variability particularly in terms of rainfall and temperature is likely to negatively influence the livestock productivity. Hence, under the changed climate scenario, the rich animal germplasm available in the country may help to sustain the livestock productivity.

\section{Policy Support and Infrastructure}

Infrastructure for livestock sector is a key area that supports for its accelerated growth. Effective and efficient delivery of animal health and production services is considered vital for livestock development and, hence, prompt delivery of livestock services has become a subject of rising concern. There are 27410 veterinary dispensaries, 25867 veterinary aid centres, 12234 veterinary hospitals and 100368 artificial insemination (AI) centres in the country (BAHS, 2017). There exist wide regional disparities in veterinary infrastructure in the country. Yadav et al. (2014) reported that the infrastructural availability for veterinary services is dominated by northern and southern regions in the country. Southern region of the country along with eastern and western region lagged behind in availability of veterinary hospitals on one hand; southern region dominated in case of veterinary dispensaries and existence of AI centers on the other. Artificial insemination is not merely a novel method of bringing about impregnation in females; it is a powerful tool mostly employed for livestock improvement. The number of artificial inseminations performed in the country has increased from 65.57 million in 201516 to 70.10 million in 2016-17. 
As far as resource allocation is concerned, the livestock sector received only about 7 per cent of the total public expenditure on agriculture and allied sectors in 2018-19. While the value of output from livestock was approximately 31.11 per cent of the value of the output from total agriculture and allied sector at constant prices (DAHD, 2018-19). Increased resource allocation to the sector would help improve the technological support as well as infrastructure required for this sector. Regional pattern of allocation of livestock research should vary from region to region and from species to species. Priority towards buffalo, equine and camel promotes efficiency; buffalo demands highest attention in livestock research $(40.2 \%)$ and followed by cattle (37.6\%), poultry $(10 \%)$ and goat $(7.9 \%)$ with all objectives in consideration (Birthal et al. 2002). Kumar et al.(2013) assessed the priorities for Indian agricultural research by regions and commodities, the study suggested that higher allocation of resources to livestock research is necessary because of the rapid increasing demand for animal products.

Livestock insurance also plays an important role in risk mitigation due to health hazards. The availability of formal insurance plans may also induce the poor and rural households to make productive investments (Farrin and Mirinda, 2015). Further, the required infrastructure for livestock marketing and processing also needs to be strengthened. Most of the livestock markets are irregular, lack transparency in transactions and are short of basic infrastructure and required facilities (DFI, Volume IV). The role of livestock infrastructure is important to comply with animal health and welfare. India is supporting the livestock sector and creating an enabling environment through livestock health \& disease control (LH\&DC), dairy entrepreneurship development scheme (DEDS), rashtriya krishi vikas yojana (RKVY), national nural livelihood mission (NRLM), Scheme for Cold Chain, Value addition and Preservation Infrastructure and many other initiatives. The target is to develop improved and high yielding breeds of domestic animals, ensure sufficient fodder, knowledge and information dissemination for improved animal health and ensure adequate marketing and processing infrastructure.

\section{Animal Health Services}

Climate change is likely to induce disease outbreaks or may even introduce new diseases, which may affect livestock that were not usually exposed to these types of diseases earlier (Thornton et al. 2009). Many diseases are expected to rise in presence of increasing climatic variations. Animal health can be directly or indirectly affected by climate change, particularly rising temperatures (Nardone et al. 2010). The direct effects are related to the increased temperature, which increases the potential for morbidity and death. The indirect effects are related to the impacts of climate change on microbial communities (pathogens or parasites), spreading of vector-borne diseases, food-borne diseases, host resistance, and feed and water scarcity (Nardone et al. 2010; Thornton et al. 2009; Tubiello et al. 2008). The outreach of veterinary health care services to the livestock farmers is low in India. It has been estimated that brucellosis costs India at least Rs.350 million every year on account of food animals and loss of man-days (Boral et al. 2009). The direct economic loss due to foot and mouth disease (FMD) in India is estimated at Rs. 20,000 crore a year (Pattnaik et al. 2012). These diseases affect the livestock farmers in the country and also affect the export potential of the livestock industry. Milk and milk products, meats and hides are not accepted by the disease-free importing countries. PPR or goat plague is the most important disease of sheep and goats causing an economic loss to the tune of Rs. 1800 million/annum (Singh, 2015). The mass scale use of PPR vaccine resulted in reduction of $>75 \%$ disease incidence. An allinclusive package about disease alertness, epidemiology surveillance, management and control measures is to be established for education at farmers' level to control the disease incidence. Facilities for veterinary health services in small ruminants are very poor. Vaccination coupled with good husbandry practices is essentially required to control the disease. Besides these, another important issue in delivery of veterinary services has been the distance covered by the household for accessing the services. It is noteworthy to mention that about 75 per cent of farmers all over India accessed veterinary services within the village to $5 \mathrm{~km}$ radius, but 25 per cent of farmers are still covering more than $5 \mathrm{~km}$ distance for accessing veterinary services as clearly. There are some states like Bihar (41.45\%), Jharkhand (41.48\%), Madhya Pradesh (48.22), Meghalaya $(63.21 \%)$ and Nagaland $(4.3 \%)$, where more than 40 per cent of farmers have to cover more than five kilometers distance for accessing veterinary health services (Yadav et al. 2014).

\section{Feeding Pattern}

One of the major constraints in livestock production is inadequacy of feed (quantity and quality) to sustain production, particularly during the dry season. The projected green fodder and dry fodder demand for 2020 is 1134, 630 million tonnes whereas the availability is expected to stand at 406 and 473 million tonnes leaving a short fall of 64 and 25 per cent, respectively (IGFRI, 2011). The concentrate requirement at 2020 has been estimated to be 81 million tonnes on dry matter basis while the estimated availability is around 45 million tonnes leaving a gap of 45 per cent (IGFRI, 2011). Although significant quantities of crop residues are produced, their quality cannot meet the nutritional requirements of livestock. New challenges in relation to forage production and feeding include climatic change and reduction of greenhouse gasses and the major challenge for small scale farmers is sustainable intensification of production, which will improve economic competitiveness and may contribute to reduction of greenhouse gases. Under feeding of sheep and goats due to scarcities of feed-fodder affecting the production and reproduction efficiency is major constraints for small ruminants (Akinmoladun et al. 2019). For poultry sector, feed raw materials availability at affordable price is a big issue. Supplementation of 
mineral mixture is inevitable to achieve optimum health, reproduction and production of livestock and poultry (Bhanderi et al. 2015).

In order to meet the nutritional requirements of animals, there is a need to increase the availability of the feed and fodders. There is also the need to encourage farmer's unions, NGOs and cooperatives to put common property lands under improved pasture systems. Research and developmental initiatives should be geared up for management of crop residues and enrichment of residues for nutrient quality and availability. Important feed ingredients for dairy cattle a can be nutritionally enhanced through genetic manipulation. Rumen biotechnology has the potential to improve the nutritive value of ruminant feedstuffs that are fibrous, low in nitrogen and of limited nutritional value for other animal species (McSweeney et al. 1999). Methods for improving rumen digestion in ruminants include the use of probiotics, supplementation with chelated minerals etc (Wadhwa et al. 2016).

\section{Conclusion and Implications}

In Indian context livestock sector over the time has acquired an important role for poverty reduction and contribution to nutritional security. India's livestock sector is both expanding and acclimatizing to the emerging socioeconomic, environmental, and technological dynamics. Livestock performs different roles, provisional to the availability of resources, environmental situations, social and economic context and the political and institutional background. If we have to shape a sustainable future for livestock in India, we need to precisely understand the diversity of numerous livestock agri-food systems and the motivations of the livestock keepers and other players involved. Presently, the livestock sector of the country needs a modernization perspective, which is optimistic about how technological innovations and affluence can help livestock sector to overcome challenges associated with shifting production and consumption pattern.

The future growth in livestock sector needs to be focused on productivity and efficiency which means mass production instead of production by mass. This implies taking initiatives for increase in productivity, harnessing economies of scale and demand driven production. It is likely that newer science tools will enhance animal productivity and make the sector a more profitable occupation. The highly trained manpower in advanced areas of livestock sector will bring about innovative changes in the management of livestock enterprise and meet the emerging requirements. Meat $\&$ meat products along with dairy products constitute majority of exports from the country. The country needs to focus on the niche items for exports and niche destinations which are profitable. However, the real challenge for Indian livestock exports would be to address the safety issues so that the Indian exporters do not face problems in foreign markets. The processing industries also need to come forward to take full advantage of price situation prevailing in the international markets. It is strongly being realized that gradual stress induced by global warming and climate change is also influencing fertility and productivity of livestock. The potentiality of science and livestock research should be harnessed by validating and transferring the technologies for enhancing animal productivity, improved value addition and improving competitiveness. There is an urgent need for developing reliable techniques for monitoring safety and quality of livestock products.

We require efficient and effective extension services, sufficient feeds \& fodder, effective animal health services, incentives for shift from subsistence livestock to livestock entrepreneurship along with efficient chains for livestock marketing and trade. The other interventions required are more intense private or public private partnerships, effective use of different subsystems by adopting a farming research systems approach to suite low external-input production systems and more adaptive research. Further we need efficient policy support and infrastructure through effective collaborations between different agencies involved in livestock development. Adequate policy support for all livestock species with regional livestock development priorities, and building capacities of livestock extension functionaries to handle the emerging challenges will provide ample impetus for the development of the Indian livestock sector.

\section{References}

Akinmoladun OF, Muchenje V, Fon FN. (2019) Small Ruminants: Farmers' Hope in a World Threatened by Water Scarcity. Animals 9:456

Akter S, Farrington J, Deshingkar P, Rao L, Sharma P, Freeman A, Reddy J (2008) Livestock drought and unreliability in India. Targeting and Innovation. ILRI (International Livestock Research Institute), Nairobi, Kenya.

Alary V, Corniaux C, Gautier D (2011) Livestock's contribution to poverty alleviation: how to measure it?. World Dev 39:1638-1648

APEDA, http://agriexchange.apeda.gov.in,

BAHS (2017), Basic Animal Husbandry \& Fisheries Statistics 2017, Government of India, Department Of Animal Husbandry, Dairying \& Fisheries Krishi Bhawan, New Delhi

Balamurugan V, Manoharan M (2013) Cost and benefit of investment in integrated broiler farming A case study. Int J Curr Res Acad Rev 2:114-23

Bardhan D (2007) India's trade performance in livestock and livestock product. Indian J Agric Econ 62:902

Berman A (2005) Estimates of heat stress relief needs for Holstein dairy cows. J Anim Sci 83:1377-1384

Bernabucci U, Lacetera N, Baumgard LH, Rhoads RP (2010) Metabolic and Hormonal Acclimation to Heat Stress in Domesticated Ruminants. Animal 4:1167-1183

Berrazaga I, Micard V, Gueugneau M, Walrand S (2019) The role of the anabolic properties of plant- versus animal-based protein sources in supporting muscle mass maintenance: A critical review. Nutrients $11: 1825$

Bettencourt EMV, Tilman M, Narciso V, Carvalho MLDS, Henriques PDDS (2015) The livestock roles in the wellbeing of rural communities of Timor-Leste. Revista de Economia e Sociologia Rural 53:63-80

Bhanderi BM, Goswami A, Garg MR, Samanta S (2016) Study on minerals status of dairy cows and their supplementation through area specific 
mineral mixture in the state of Jharkhand. J Anim Sci Technol $58: 42-49$

Birthal PS (2008) Linking smallholder livestock producers to markets: Issues and approaches. Indian J Agric Econ 63:19-37

Birthal PS (2008) Making contract farming work in smallholder agriculture. New Delhi: National Centre for Agricultural Economics and Policy Research.

Birthal PS, Chand R, Joshi P, Saxena R, Rajkhowa P, Khan MT, Khan MA, Chaudhary KR (2017) Formal versus informal: Efficiency, inclusiveness and financing of dairy value chains in Indian Punjab. J Rural Stud 54:288-303

Birthal PS, Joshi PK, Kumar A (2002) Assessment of research priorities for livestock sector in India, Policy Paper 15, National Centre for Agricultural Economics and Policy Research (ICAR), New Delhi, India

Birthal PS, Negi DS (2012) Livestock for higher, sustainable and inclusive agricultural growth. Econo Political Weekly 47:89-99

Birthal PS, Taneja VK (2006) Livestock sector in India: Opportunities and Challenges, presented at the ICAR-ILRI workshop on 'Smallholder livestock production in India' held during January 2425, 2006 at NCAP, New Delhi 110012

Birthal PS, Taneja VK (2012) Operationalizing the pro-poor potential of livestock: Issues andstrategies. Indian J Anim Sci 82:441-447

Birthal PS, Taneja VK, Thorpe W (2006) Smallholder livestock production in India: Opportunities and challenges, National Centre for Agricultural Economics and Policy Research, New Delhi, India \& International Livestock Research Institute, Nairobi, Kenya.

Boral R, Singh M, Singh DK (2009) Status and strategies for control of brucellosis-a review. Indian J Anim Sci 79:1191-1199

Candler W, Kumar N (1998) India: the dairy revolution: the impact of dairy development in India and the World Bank's contribution, World Bank, Washington, D.C.

Chand R (2017) Doubling Farmer's Income: Rationale, Strategy, Prospects and Action Plan, NITI Policy Paper No. 01/2017

Choudhary BB (2017) Climate sensitivity of agricultural production system in trans and upper Gangatic plains of India: potential economic impact and vulnerability. Ph.D. thesis, National Dairy Research Institute, Karnal, India

Choudhary BB, Sirohi S (2019) How sensitive are buffaloes (Bubalus bubalis) to heat stress? J Dairy Res 86:399-405

Cunningham K (2009) Rural and Urban Linkages Operation Flood's Role in India's Dairy Development, IFPRI Discussion Paper 00924

Das VK, Kumar AG (2017) Drivers of farmers' income: The role of farm size and diversification, working paper 013, Indira Gandhi Institute of Development Research, Mumbai

DFI, Volume IV, Ministry of Agriculture and Farmers' Welfare, Government of India, New Delhi

Dhakal CK, Regmi PP, Dhakal IP, Khanal B, Bhatta UK, Barsila SR, Acharya B (2013) Perception, impact and adaptation to climate change: an analysis of livestock system in Nepal. J.

Dikshit AK, Birthal PS (2013) Positive environmental externalities of livestock in mixed farming systems of India. Agric Econ Res Rev 26:21-30

Duflo E (2003) Grandmothers and granddaughters: Old age pension and intra-household allocation in South Africa. World Bank Econ Rev $17: 1-25$

Farrin K, Miranda M (2015) A Heterogeneous agent model of creditlinked index insurance and farm technology adoption. J Dev Econ 116:199-211

FICCI (2015), Overview of The Indian buffalo meat value chain, New Delhi, available at http://ficci.in/spdocument/20331/Overview-ofThe-Indian-Buffalo-meat-value-chain.pdf
Funk S, Gilad E, Watkins C, Jansen VA (2009) The spread of awareness and its impact on epidemic outbreaks. Proceedings of the National Academy of Sciences 106:6872-6877

Gadekar YP and Shinde AK (2011). Indian meat industry: opportunities and challenges. Indian Food Ind 30:17-22

Gaughan JB, Lacetera N, Valtorta S E, Khalifa HH, Hahn L, Mader T (2009) Response of Domestic Animals to Climate Challenges. Biometeorology of Adaptation to Climate Variability and Change, pp. $131-170$

Ghandi VP, Zhou Zhang-Yue (2010) Rising demand for livestock products in India: nature, patterns and implications. Australasian Agribusiness Rev 18:103-135

Górska-Warsewicz H, Laskowski W, Kulykovets O, Kudliñska-Chylak A, Czeczotko M, Rejman K (2018) Food products as sources of protein and amino acids - the case of Poland. Nutrients 10:1977

Goyal TM, Mukherjee A, Kapoor A (2017) India's Exports of Food Products: Food Safety Related Issues and Way Forward. Working Paper No. 345. Indian Council for Research on International Economic Relations.

Hitchings JA (1982) Agricultural Determinants of Nutritional Status Among Kenyan

IFAD (2003) International Fund for Agricultural Development. 2003. Mainstreaming a Gender Perspective in IFAD's Operations: Plan of Action, Prerequisites of Gender-sensitive Design. Rome: IFAD.

IFAD (2010) Promotion of women's leadership in farmers 'and rural producers' organisations. Special session of the third global meeting of the Farmers' Forum, IFAD, Rome, February 12-13, 2010.

IGFRI (2011), Vision 2030, Indian Grassland and Fodder Research Institute Jhansi (UP), Jhansi

Kanwal V (2018) Analysis of risk and vulnerability of rural farm households to natural disasters in Rajasthan. Ph.D. Thesis, National Dairy Research Institute, Karnal.

Kennedy KC (2000) Resolving International Sanitary and Phytosanitary Disputes in the WTO: Lessons and Future Directions, 55 Food \& Drug L.J. 81, 99

Kumar A (2009) India's Livestock Sector Trade: Opportunities and Challenges, NCAP Policy Paper 24. National Centre for Agricultural Economics and Policy Research, New Delhi

Kumar A (2010) Exports of livestock products from India: Performance, Competitiveness and Determinants. Agricultural Economics Research Review 23, no. 347-2016-17033: 57-68

Kumar A (2010) Exports of livestock products from India: Performance, Competitiveness and Determinants. Agric Econ Res Rev 23:57-68

Kumar A, Dhiraj K Singh (2008) Livestock production systems in India: an appraisal across agro-ecological regions. Indian Journal of Agricultural Economics 63, no. 902-2016-67979

Kumar A, Joshi PK, Kumar P, Parappurathu S, (2014) Trends in the consumption of milk and milk products in India: implications for self-sufficiency in milk production. Food Security 6:719-726

Kumar A, Singh DK (2008) Livestock production systems in India: an appraisal across agro-ecological regions. Indian J Agric Econ 63:577597

Kumar A, Steven JS, Elumalai K, Singh DK (2007) Livestock sector in north-eastern region of India: An appraisal of performance. Agric Econ Res Rev 20:255-272

Kumar A, Steven JS, Singh NP, Singh DK (2007) Livestock sector trade of India: Surging momentum in the new liberalised regime. Indian Journal of Agricultural Economics 62, no. 902-2016-68003

Kumar P (2016) Demand vs supply of food in India-Futuristic projection. Proceedings of the Indian National Science Academy 82:1579-86

Kumar P, Kumar A, Parappurathu S, Raju SS (2011) Estimation of demand elasticity for food commodities in India. Agric Econ Res Rev 24:114 
Kumar P, Madan MD (2007) Long-term changes in Indian food basket and nutrition. Econ Political Weekly:3567-3572

Kumar S, Raju BMK, Ramarao CA, Ramilan T (2015) Sensitivity of livestock production to climatic variability under indiandrylands and future perspective. Current Agriculture Research Journal 3, no. 02: $142-149$

Kumar S, RamRao CA, Kareemulla K, Venkateswarlu B (2010) Role of goats in livelihood security of rural poor in the less favoured environments. Indian Journal of Agricultural Economics 65(4)

Maust LERE, McDowel RE, McDowell, Hooven NW (1972) Effect of summer weather on performance of Holstein cows in three stages of lactation. J Dairy Sci 55:1133-1139

McSweeney CS, Dalrymple BP, Gobius KS, Kennedy PM, Krause DO, Mackie RI, Xue GP (1999) The application of rumen biotechnology to improve the nutritive value of fibrous feedstuffs: pre-and postingestion. Livest Prod Sci 59:265-83

McSweeney CS, Palmer B, Bunch R, Krause DO (1999) In uitro quality assessment of tannin-containing tropical shrub legumes: protein and fibre digestion. Anim Feed Sci Technol 82:227-241

Mellor JW (2004) Agricultural Growth and Poverty Reduction: The Rapidly Increasing Role of Smallholder Livestock, in Ahuja, Vinod (Editor). Livestock and Livelihoods: Challenges and Opportunities for Asia in the Emerging Market Environment, National Dairy Development Board of India and FAO of the United Nations. 372p

Mittal S (2007) What affects changes in cereal consumption? Econ Political Weekly: 444-447

Nardone A, Ronchi B, Lacetera N, Ranieri MS, Bernabucci U, (2010) Effects of climate changes on animal production and sustainability of livestock systems. Livest Sci130:57-69

NITI (2018) Demand \& Supply Projections Towards 2033 Crops, The Working Group Report, NITI Aayog, New Delhi

NRC (2001) Nutrient Requirement of Dairy Cattle. National Research Council (NRC) National Academy Press, Washington, DC, USA

Nyamushamba G, Mapiye C, Tada O, Halimani T, Muchenje V (2017) Conservation of indigenous cattle genetic resources in Southern Africa's smallholder areas: turning threats into opportunities-A review. Asian-Australas J Anim Sci 30:1-19

Pankaj PK, Ramana DBV, Pourouchottamane R, Naskar S (2013) Livestock management under changing climate scenario in India. World J Vet Sci $1: 25-32$

Pattnaik B, Subramaniam S, Sanyal A, Mohapatra JK, Dash BB, Ranjan R, Rout M (2012) Foot-and-mouth disease: global status and future road map for control and prevention in India. Agric Res 1:132-147

Phaniraja KL, Panchasara HH (2009) Indian Draught Animals Power. Vet World 2:404-407

Planning Commission (2012) Government of India (2012) Report of the Working Group on Animal Husbandry \& Dairying 12th Five Year Plan (2012-17), Planning Commision, New Delhi.

Priya VP, Sundari MM (2015) Case Study: Institutional and socioeconomic factors influencing the participation of Indian farmers in poultry farming. Adv Manage 1:10

Quisumbing AR, Maluccio JA (2003) Resources at marriage and intrahousehold allocation: Evidence from Bangladesh, Ethiopia, Indonesia, and South Africa. Oxford Bull Econ Stat 65:283-327

Rajendran K, Mohanty S (2004) Dairy co-operatives and milk marketing in India: Constraints and opportunities. J Food Distribution Res $35: 34-41$

Rao CK, Bachhman F, Sharma V, Venkataramaiah P, Panda J, Rathinam R (2014) Smallholder dairy value chain development in India and selected states (Assam and Bihar): situation analysis and trends

Rota A, Sperandini S (2010) Value chains, linking producers to the markets. Livestock thematic papers, International Fund for Agricultural Development (IFAD), Rome, Italy
Salmon G, Teufel N, Baltenweck I, Van WM, Claessens L, Marshall K (2018) Trade-offs in livestock development at farm level: Different actors with different objectives. Global Food Security 17:103-112

Saxena R, Singh NP, Choudhary BB, Balaji SJ, Paul RK, Ahuja U, Joshi D, Kumar R, Khan A (2017) Can Livestock Sector be the Game Changer in Enhancing the Farmers' Income? Reinvesting Thrust with Special Focus on Dairy Sector. Agric Econ Res Rev 30:59-76

Senauer B (1990) The impact of the value of women's time on food and nutrition, in TINKER (ed), Persistant Inequalities. Woman and World Development, NewYork/Oxford: Oxford University Press, pp. 150161

Singh RP, Bandyopadhyay SK (2015) Peste des petits ruminants vaccine and vaccination in India: sharing experience with disease endemic countries. Virus Dis 26:215-224

Sirohi S, Axel M (2007) Sufferer and cause: Indian livestock and climate change. Climatic Change 85: 285-298

Sirohi S, Chauhan AK (2011) Current scenario of livestock development and potential interventions for livelihood improvement: Case of Jharkhand, India. Background Paper. ELKS Publication Series 2. ILRI, Nairobi, Kenya

Smith LC, Ramakrishnan U, Ndiaye A, Haddad L, Martorell R (2003) The Importance of Women's Status for Child Nutrition in Developing Countries: International Food Policy Research Institute (Ifpri) Research Report Abstract 131. Food Nutr Bull 24:287-8

Sorathiya LM, Fulsoundar AB, Tyagi KK, Patel MD, Singh RR (2014) Eco-friendly and modern methods of livestock waste recycling for enhancing farm profitability. Int J Recycl Org Waste Agric1: 50

Srivastava AK, Patel JB, Ankuya KJ, Chauhan HD, Pawar MM, Gupta JP(2019)Conservation of Indigenous Cattle Breeds. J Anim Res 9:12

Steinfeld H, Gerber P, Wassenaar T, Castel V, Rosales M, de Haan C (2006) Livestock's long shadow: Environmental issues and options. FAO, Rome, Italy

Thornton PK, Van de SJ, Notenbaert A, Herrero M (2009) The impacts of climate change on livestock and livestock systems in developing countries: A review of what we know and what we need to know. Agricu Syst 101:113-127

Umanath M, Vijayasarathy K, Pradeepa BN (2016) Determinants of preference for and consumption of liquid milk by Indian households. Indian J Dairy Sci 69:498-504

Upadhyay RC, Hooda OK, Aggarwal A, Singh SV, Chakravarty R, Sirohi S (2013) Indian livestock production has resilience for climate change. Climate Resilient Livestock Production System

Wadhwa M, Bakshi MP, Makkar HP (2016) Modifying gut microbiomes in large ruminants: Opportunities in non-intensive husbandry systems. Anim Front 6:27-36.

West JW, Mullinix BG, Bernard JK (2003) Effects of Hot, Humid Weather on Milk Temperature, Dry Matter Intake, and Milk Yield of Lactating Dairy Cows. J Dairy Sci 86:232-242

World Bank (2010) Demand Led Transformation of the Livestock Sector in India. Achievements, Opportunities, and Challenges, South Asia Agriculture and Rural Development." Report No. 48412 IN. The World Bank. Washington, DC.

World Bank (2011) Demand-Led Transformation of the Livestock Sector in India Achievements, Challenges, and Opportunities, World Bank, Washington, DC

WTO (2001) Decision on the Implementation of Article 4 of the Agreement on the Application of Sanitary and Phytosanitary Measures (G/SPS/ 19)

Yadav P, Chandel BS, Sirohi S (2014) Infrastructure disparities in rural India: With special reference to livestock support services and veterinary infrastructure. Int J Livest Prod 5:147-154 